Cahiers $d u$ MONDE RUSSE

\section{Cahiers du monde russe}

Russie - Empire russe - Union soviétique et États indépendants

$57 / 4 \mid 2016$

Varia

\title{
The Liberal Doctrine of Civil Rights in Late Imperial Russia
}

A history of the struggle for the rule of law

La doctrine libérale des droits civils en Russie à la fin de l'époque impériale:

histoire de la lutte pour l'État de droit

\section{Anastasiya Tumanova}

\section{OpenEdition \\ Journals}

\section{Electronic version}

URL: http://journals.openedition.org/monderusse/9990

DOI: 10.4000/monderusse.9990

ISSN: $1777-5388$

Publisher

Éditions de l'EHESS

\section{Printed version}

Date of publication: 1 October 2016

Number of pages: $791-818$

ISBN: 978-2-7132-2542-0

ISSN: $1252-6576$

Electronic reference

Anastasiya Tumanova, «The Liberal Doctrine of Civil Rights in Late Imperial Russia », Cahiers du monde russe [Online], 57/4 | 2016, Online since 01 October 2018, Connection on 07 January 2020. URL : http://journals.openedition.org/monderusse/9990; DOI : 10.4000/monderusse.9990 


\title{
THE LIBERAL DOCTRINE OF CIVIL RIGHTS IN LATE IMPERIAL RUSSIA
}

\author{
A history of the struggle for the rule of law ${ }^{1}$
}

\section{The issue and how it was approached}

Individual liberty is the fundamental principle of liberalism, with inalienable rights of society members being the building blocks of the legal theory of liberalism. The establishment of civil rights as a foundation for the political-legal doctrine of Russian liberalism is based on a strong historical tradition. My intention is to discuss late imperial Russia's experience in designing a logical, unified construction of inviolable individual rights, which was a theoretical justification for the constitutionalism of the early twentieth century. This construction was due to the school of "revived" (vozrozhdennyi) natural law, which was the most authoritative

1. This article is an output of a research project implemented as part of the Basic Research Program at the National Research University Higher School of Economics (HSE). Some aspects of this paper were reflected in the preprint of the Higher School of Economics (Anastasiya S. Tumanova, "Subjective Public Rights in the Legal Philosophies of Russian Liberalism in the Early 20th Century," Series: Law, WP BRP 25/LAW/2013). The paper was translated into English by Associate Professor Juri Zusman (Tambov State University named after G.R. Derzhavin) and Professor Alexandra Nagornaya (Moscow City University). The author greatly appreciates their help. The author wishes to express gratitude to the first reader of this manuscript, Professor Adele Lindenmeyr, who made an invaluable contribution to its revision. The main ideas of this paper were presented by the author at the "Trajectories of Law and Sovereignty" workshop (7-8 April 2016) at Wissenschaftskolleg zu Berlin. The author would like to thank Jane Burbank, Peter Holquist and Kathryn Hendley for their opinions and proposals. Finally, she is especially grateful to the anonymous referees of Cahiers du Monde russe for their helpful advice and suggestions. 
in Russian legal philosophy at the beginning of the twentieth century. ${ }^{2}$ Prerevolutionary Russia's wealth of legal philosophy, the search for the ideal meaning of law, and the prominence of its leading representatives, enable me to claim that the turn of the twentieth century was the "golden age" of Russian legal thought.

Prominent Russian liberally oriented legal scholars such as Pavel Novgorodtsev, Vladimir Solov'ev, Bogdan Kistiakovskii, Evgenii Trubetskoi, Vladimir Gessen, and others were engaged in the development of the concepts of "revived" natural law and the rule-of-law state (pravovoe gosudarstvo). Within the framework of these concepts, they formulated a detailed theory of civil rights and liberties. Prerevolutionary Russian legal philosophies substantiated the idea that civil rights and liberties were natural, inalienable for citizens and inviolable by public authority; their recognition, observance, and protection were considered an integral duty of the state. They suggested that rights form the basis for the legal doctrine that recognizes their natural character as the most essential factor in the formation of laws. Legal philosophers believed that the necessary condition for the success of reforms was their correspondence to the type of legal consciousness ${ }^{3}$ that could be found in educated society. According to Michel Tissier, the priority of civil rights was the fundamental characteristic of the legal consciousness of the Russian educated public, especially liberal lawyers, in 1905 and 1906. ${ }^{4}$ These ideas were in great demand in the twentieth century.

The study of the doctrine of the "revived natural law" school is instructive for modern Russian jurisprudence, which has freed itself from the chains of the Marxist dogma and been seeking alternative legal concepts over the last two decades. ${ }^{5}$ The results obtained by the representatives of this school, such as the priority of the rule-of-law state and individual rights, have a heuristic potential for modern lawmaking in Russia, which is attempting to work out conceptions of legal policy and reform the Russian legal system as a whole. Since these ideas are deeply rooted

2. Alongside this theory, Russia saw the development of sociological jurisprudence and juridical positivism, which also had highly influential representatives. The views of the most prominent representatives of these schools on civil rights and rule-of-law state will also be briefly considered in this paper.

3. Legal consciousness is understood as a system of legal views, ideas, notions, beliefs and assessments that reflect the attitude of individuals, social groups and the society as a whole towards existing or desirable law and towards legal phenomena, as well as various types of legal behavior. The paper focuses on the legal consciousness of representatives of Russian educated society, primarily the juridical elite.

4. Michel Tissier, "Kakoe iuridicheskoe prosveshchenie nuzhno v Rossii? Perekhod ot populiarizatsii prava $\mathrm{k}$ populiarizatsii grazhdanskikh prav [What kind of legal education do Russians need? From popularizing the law to popularizing civil rights]," Neprikosnovennyi zapas, no. 6 (2005): 58-62.

5. A more detailed analysis of contemporary Russian legal theories, such as the communicative and anthropological theories, can be found in Teoriia pravovoi kommunikatsii $i$ problemy sovremennoi iurisprudentsii: Esse $v$ chest' shestidesiatiletiia professora Andreiia $V$. Poliakova [Theory of legal communication and issues in contemporary jurisprudence: An essay in honor of the sixtieth anniversary of Professor Andrei V. Poliakov] (SPb.: Alef-press, 2014); Il.L. Chestnov, Postklassicheskaia teoriia prava [Postclassical theory of law] (SPb.: Alef-press, 2012). 
in the European philosophical and legal tradition of the Modern Period and yet reflect specific features of the Russian legal culture, they make it possible to give answers to the basic questions of political and legal life (regarding the correlation of rights and law, rights and morality, state and person, etc.).

Certain aspects of the institutionalization of civil rights in liberal juridical theory and political philosophy of late imperial Russia have already been discussed in academic literature. Andrzej Walicki's monograph on the philosophical and legal heritage of Russian liberalism provides an analysis of the philosophical legal theories that were fundamental for the Russian intellectual liberal tradition between the second half of the nineteenth and the beginning of the twentieth centuries. Alongside the "old liberal" legal philosophy represented by Boris Chicherin's legacy, Walicki examines the origins of legal philosophy in the works of Vladimir Solov'ev, Pavel Novgorodtsev, and Bogdan Kistiakovskii, searching for their basic ideas on "new liberalism."6

The foundational monograph by the Russian philosopher Andrei Medushevskii describes the influence of the ideas of Pavel Novgorodtsev, Vladimir Gessen, Bogdan Kistiakovskii, Sergei Kotliarevskii, and other jurists on the jurisprudence of the early twentieth century. He points out their adherence to the liberal paradigm of social restructuring, the idea of the rule of law and the strategy of modernization without revolution. ${ }^{7}$

Philosopher Viacheslav Zhukov values the "revived natural law" school for uniting a wide range of liberal thinkers of different methodological backgrounds (Neo-Kantianism, Neo-Hegelianism, personalism), for imbibing national peculiarities of Russian philosophy and legal culture, and for combining the principle of individualism with social and state interests. ${ }^{8}$ Lawyer Andrei Poliakov points out that the representatives of this school resolved the basic issue of legal theory about the notion of law and its essential features, in particular the crucial importance of moral principles, which constitute the criterion that the law must meet. ${ }^{9}$

Apart from the listed works dealing with the rights of Russian citizens at the beginning of the twentieth century, thus far there has been no generalizing research enabling us to assess the status and extent of the theoretical elaboration of the topic.

6. Andrzej Walicki, Legal Philosophies of Russian Liberalism (Oxford: Clarendon Press, 1987).

7. A.N. Medushevskii, Dialog so vremenem: Rossiiskie konstitutsionalisty kontsa XIX nachala $X X$ veka [A dialogue with time: Russian constitutionalists in the late nineteenth - early twentieth centuries] (M.: Novyi khronograf, 2010).

8. V.N. Zhukov, Russkaia filosofiia prava: Estestvenno-pravovaia shkola pervoi poloviny $X X$ veka [Russian philosophy of law: The natural law school of the first half of the twentieth century] (M.: Rossiiskoe gumanisticheskoe obshchestvo, 2001), 125, 214.

9. A.V. Poliakov, "Mozhet li pravo byt' nepravym? Nekotorye aspekty dorevoliutsionnogo rossiiskogo pravoponimaniia [Can the law be wrong? Some aspects of prerevolutionary Russian understanding of law]," Izvestiia vysshikh uchebnykh zavedenii. Pravovedenie, no. 4 (1997): 95-104. See also: Poliakov, "Proshchanie s klassikoi ili kak vozmozhna kommunikativnaia teoriia prava [Farewell to classics, or What makes a communicative law theory possible]," Rossiiskii ezhegodnik teorii prava, no. 1 (2008): 9-43. 
The topicality and importance of such research is supported by Jane Burbank's judgment that the study of legal history in Russia should be based mainly on the conceptions of law developed by Russian intellectuals of the late nineteenth and early twentieth centuries, and that the range of ideas they proposed was still topical for Russia in the late twentieth century. ${ }^{10}$

\section{A revival of the understanding of law based on a moral ideal}

At the turn of the twentieth century, Russian liberalism entered a new period of development. Its classical form, the political and legal doctrine of which was represented by the ideas of Boris Chicherin, Konstantin Kavelin, and Aleksandr Gradovskii, was replaced by a trend called "new liberalism." This term was suggested in 1911 by the English sociologist Leonard Hobhouse to denote a doctrine rejecting nineteenth-century classical liberalism with its ideas of a minimal state and freedom of the individual from constraints. Besides putting forward the ideas listed above, it substantiated the individual's right to demand minimal social benefits and guarantees of a dignified life from the state. This new type of Russian liberalism was aimed at bringing forth progressive changes in political and legal life through the development of philosophical and legal theory. The revival of natural law became such a theory, and the jurists Pavel Novgorodtsev, Bogdan Kistiakovskii, Evgenii Trubetskoi, Vladimir Gessen, Sergei Kotliarevskii, Iosif Pokrovskii, and others became its ideologists. The legal doctrine of new liberalism was based on the ideas of the rule of law and representative form of governance. The concept of "natural," inviolable, and inalienable civil rights and freedoms lay at its core.

In his description of the ideological spirit of Russian jurisprudence of the early twentieth century, Iosif Pokrovskii made his own the words of his well-known contemporary, the German jurist Otto von Gierke: "We must find it, the lost legal idea, or we'll lose ourselves!"11 In Pokrovskii's opinion, "the spirit of this quest" reflected the state of jurisprudence in prerevolutionary Russia, which could not be satisfied with studying current legislation, and was doomed without "great ideas" and "general truths" and without studying the legal idea. The role of "servant of the law" (sluzhanka zakonodatel'stva) did not suit this quest. Using this philosophy, the followers of neo-Kantianism were able to reconsider existing (positive) law from the perspective of moral ideals and the category of "necessity," to contrast the existing legal system of the Russian autocracy with the concept of liberal judicial reform.

10. Jane Burbank, "Legal Culture, Citizenship, and Peasant Jurisprudence: Perspectives from the Early Twentieth Century," in Peter H. Solomon, ed., Reforming Justice in Russia, 1864-1996: Power, Culture, and The Limits of Legal Order (New York: M.E. Sharpe, 1997), 84

11. I.A. Pokrovskii, Osnovnye problemy grazhdanskogo prava [Basic issues in civil law] (M.: Statut, 1998, originally published in 1917), 75-76. 
The revival of natural law was typical of jurisprudence in a number of European countries in the late nineteenth and early twentieth centuries, such as France, Germany, and Italy. The original version of this theory - the school of natural law - dominated European jurisprudence in the seventeenth and eighteenth centuries. Among its most prominent representatives were Hugo Grotius, Thomas Hobbes, Samuel von Pufendorf, John Locke, Jean-Jacques Rousseau. Reflecting on the appeal of the natural law theory in Russia and its European forerunners, the Russian historian Aleksandr Aleksandrovich Kizevetter focused on its two key aspects:

The social contract doctrine leads us to the conclusion that changing the existing political system is possible. [...] The doctrine that inherent human rights correspond to human nature sets limits to the state's interference in civil society and the citizen's private life..$^{12}$

In Russia, the "revived natural law" theory emerged in the mid-1890s. The legal philosophers Leon Petrażycki ${ }^{13}$ and Pavel Novgorodtsev ${ }^{14}$ were the first to claim, in their works published in 1896 and 1897, that it was necessary to revive natural law. The ideology of this trend in legal thought was formulated by Novgorodtsev in a 1902 article on moral idealism. The philosopher admitted that current legal scholarship was in crisis, that "critical spirit and deep philosophical yearning had disappeared [...], [that] practical interests prevailed, and work [in legal scholarship] had become minor, corporate and confined." In his opinion, the situation could be redeemed only by "the revival of natural law with its a priori method, ideal aspirations, recognition of the importance of individual autonomy as a moral principle and regulatory consideration." 15 In a speech at St. Petersburg University in 1902, Novgorodtsev declared war on historicism, positivism, and naturalist evolutionism, and defended idealism, moral private autonomy, and the regulatory principle. He declared that revival and restoration of "the ideal significance of law, its moral principle" were the main tasks of modern legal philosophy. He called for a methodological change in the study of law, for a rejection of dogmatic formal legal interpretation in favor of normative interpretation, and for consideration of

12. A.A. Kizevetter, Istoricheskie ocherki [Historical essays] (M.: Tovarishchestvo A.A. Levenson, 1912), 62.

13. L.I. Petrazhitskii [Leon Petrażycki], "Vvedenie v politiku prava [Introduction to the politics of law]," Kievskiie Universitetskie Izvestiia, no. 8 (1896), no. 9-10 (1897).

14. P.I. Novgorodtsev, Istoricheskaia shkola iuristov, ee proiskhozhdenie i sud'ba: Opyt kharakteristiki osnov shkoly Savin'i v ikh posledovatel'nom razvitii [The historical school of jurists, its origins and fate: A description of the basic principles of the Savigny School in their consistent development] (M.: Universitetskaia tipografiia, 1896).

15. P.I. Novgorodtsev, "Nravstvennyi idealizm v filisofii prava (K voprosu o vozrozhdenii estestvennogo prava) [Moral idealism in legal philosophy (On the issue of reviving natural law)]," in O svobode: Antologiia mirovoi liberal'noi mysli (I polovina XX veka) [On freedom: An anthology of the world's liberal thought (first half of the twentieth century)] (M.: Progress Traditsiia, 2000), 598, 600-601, originally published in 1902 in P.I. Novgorodtsev, ed., Problemy idealizma [Issues in idealism] (M., 1902), 236-296. 
law as part of social reality with reference to History, Sociology, Psychology, Ethics, and other fields. ${ }^{16}$

Novgorodtsev referred to the ideas of the distinguished legal philosopher, and his oldest contemporary, Vladimir Solov'ev, which were the basis for the concept of revived natural law (which the latter enthusiastically supported), and paid special attention to the moral value of legal institutions and their importance for moral progress. Solov'ev and Novgorodtsev contrasted law based on tyranny and violence with law as an expression of justice and freedom. ${ }^{17}$ According to Solov'ev, law could not be understood as an independent principle separate from morality. The philosopher defined law as "the lowest limit" or "certain minimum" of morality. At the same time, Solov'ev did not oppose natural law to positive law. For him, natural law was a synonym of justice (spravedlivost' ${ }^{\prime}$ ), which meant freedom and equality; positive law was the historical manifestation of law, the true content of any specific law and was realized in a certain society to an extent that was determined by its degree of moral consciousness.

The methodological basis for the "revived natural law" doctrine in Russia was the philosophy of Neo-Kantianism, based on the concept of the dialectic of das Sein and das Sollen, and the need to study social phenomena in two ways: as they are, and as they should be. It was the revival of philosophical individualism visible in Germany in the early 1860 s, which called for a return to Kant, and then of the Neo-Kantian movement, which finally led to the revival of the idea of natural rights. As the legal scholar Bogdan Kistiakovskii, an eminent representative of the Neo-Kantian movement in Russia, wrote in his main work, published in 1916:

The idea of natural law has been revived in a new formula [...]. It is this idea, critically checked and purified by Neo-Kantianism, that serves as one of the ideological foundations for guaranteeing human rights. ${ }^{18}$

On the basis of this philosophy, natural law revivalists tried to draw a distinction between das Sein and das Sollen, and assess reality (notably, the legal system and political regime of autocratic Russia) from the standpoint of how things ought to be (a moral ideal, specific embodiments of which include the establishment of the rule-of-law state and securing the rights and freedoms of the individual).

Natural law is a synonym of how things ought to be in law, wrote Evgenii Trubetskoi, a member of the new school. It is a moral basis for any specific legal

16. Walicki, Legal Philosophies of Russian Liberalism, 302-310.

17. P.I. Novgorodtsev, Ideiia prava $v$ filosofii VI.S. Solov'eva [The idea of law in V1.S. Solov'ev's philosophy] (M.: Tipo-litografiia Tovarishchestva I.N. Kushnerevi K., 1901), $17,19$.

18. B.A. Kistiakovskii, "Sotsial'nye nauki i pravo. Ocherki po metodologii sotsial'nykh nauk i obshchei teorii prava [Social sciences and law. Essays on the methodologies of the social sciences and general law theory]," in B.A. Kistiakovskii, Izbrannye trudy [Selected works], Vol. 1 (M.: ROSSPEN, 2010), 479, originally published in 1916. 
order [...], an appeal to improve the current law. It is a prerequisite for progress and development in law. Progress, i.e., the progressive advance of law towards good, is possible only insofar as positive law is subject to a higher moral or natural law, which serves as its basis and criterion. ${ }^{19}$

Ivan Il'in, another representative of this school, pointed out that natural law was based on the requirements of justice:

The relationship between law and morality can be formed rightly and wrongly. The right relationship between them exists only when law, without exceeding its limits, conforms to the requirements of morality and is a preparatory stage and support for it... ${ }^{20}$.

Il'in considered positive law to be "an imperfect manifestation or an immature formula of natural law" which was to "take the content of natural law and display it as a number of rules of external behavior adapted to the specific conditions of life and the requirements of a specific time." ${ }^{21}$

However, the natural law theory required that renovation and improvement in Russia become a generator of social reforms. This brought about the theory of "natural law with changeable content" (estestvennoe pravo s izmenchivym soderzhaniem). Suggested by Rudolf Stammler, a supporter of Neo-Kantianism, and Boris Chicherin in the second half of the nineteenth century, and found partly in Kant's works, this theory was brought into being by the urge to overcome the dualism of views in the old school of natural law, which contrasted natural law with positive law. Chicherin predicted the gradual harmonization of positive law and natural law in the course of the historical development of society and the creation of a social order under which individual political freedom would achieve its completion. ${ }^{22}$ The renewal of the natural law concept in the late nineteenth and early twentieth centuries in the form of revived natural law made it less vulnerable to criticism by its opponents, the supporters of positivistic theories.

19. E.I. Trubetskoi, Entsiklopediia prava [Encyclopedia of law] (M.: Skoropechatnia A.A. Levenson, 1908), 59.

20. I.A. Il'in, "Obshchee uchenie o prave i gosudarstve," in Osnovy zakonovedeniia: Obshchee uchenie o prave i gosudarstve $i$ osnovnye poniatiia russkogo gosudarstvennogo, grazhdanskogo i ugolovnogo prava [Fundamentals of law: General doctrine of law and state and the basic concepts of the Russian state, civil and criminal law] (M.: Izdanie Tovarishchestva V.V. Dumnov, 1915), 32-33.

21. I.A. Il'in, $O$ sushchnosti pravosoznaniia [On legal consciousness] (Munich: Tipografia Obiteli Prepodobnogo Iova Pochaevskogo, 1956), 44, 46.

22. B.N. Chicherin, Sobstvennost' i gosudarstvo [Property and state], part 1 (M.: Tipografiia Pravitel'stvuiushchego Senata, 1881), 87. 


\section{The concept of the individual and the individual's fundamental rights and freedoms}

The concept of the individual formed the basis for the natural law revivalists' legal theory. At the beginning of the twentieth century in Russia, revived natural law became a science expressing "the absolute significance of the individual, which should belong to the individual in any form of political system." 23

January 1905 saw the first issue of the literary-social journal Voprosy zhizni edited by the philosopher Nikolai Losskii. In this first issue, the journal published Kistiakovskii's article about the rights of man and of the citizen, which was a policy statement, because it formulated the task of establishing a constitutional order in Russia and admitted the utmost significance of the individual and his or her rights. Kistiakovskii called for the recognition of the significance of individuals, for imbuing them with the awareness of their rights, and for inducing them to struggle for their rights. The legal scholar proposed that all citizens, including those who were not supporters of the natural law theory, should be aware of the fact that "the individual has inalienable rights that cannot be violated by the state." ${ }^{24}$

In 1908, Kistiakovskii wrote:

State interests in no way should take over the interests of certain individuals. The individual is not simply a means for the state $[\ldots]$. When the individual is just a means for the state, the state becomes a despot whose power grows into pure lawlessness. Such despotism is typical of an absolute monarchy state. Interests of the state and authority here are everything, while the individual is nothing. A state becomes constitutional only if the following principle is established: the individual exists independently of the state and has priority over it. ${ }^{25}$

The main message of Kistiakovskii's doctrine consisted in the substantiation of the further development of individual freedoms in an unfree society, and in upholding the legal ethics of "subjective public rights." ${ }^{26}$ Kistiakovskii's recognition of the fact that civil rights theory was a significant part of the conception of a rule-of-law state was an important contribution to the development of national law. ${ }^{27}$

23. Novgorodtsev, Nravstvennyi idealizm v filosofii prava, 636.

24. B.A. Kistiakovskii, "Prava cheloveka i grazhdanina [The rights of man and of the citizen]," Voprosy zhizni, no. 1 (1905): 123, 142.

25. B.A. Kistiakovskii, "Gosudarstvennoe pravo (obshchee i russkoe). Lektsii B.A. Kistiakovskogo, chitannye v Moskovskom kommercheskom institute v 1908/1909 akademicheskom godu [State law (general and Russian). Lectures by B.A. Kistiakovskii, delivered at the Moscow Institute of Commerce in the 1908-1909 academic year]," in B.A. Kistiakovskii, Izbrannye raboty [Selected works] part 2 (M.: ROSSPEN, 2010), 191.

26. Medushevskii, Dialog so vremenem, 383.

27. Susan Heuman, Kistiakovskii: The Struggle for National and Constitutional Rights in the Last Years of Tsarism (Cambridge: Harvard University Press, 1998), 65; Walicki, Legal Philosophies of Russian Liberalism, 367. 
Kistiakovskii insisted that public authority should recognize the rights of the individual as immutable and inviolable and establish them de jure. He considered the declarations of civil rights of the eighteenth century - especially the Declaration of the Rights of Man and of the Citizen of 1789 in France - to be significant acts which marked a real turning point in the development of modern legal consciousness in western countries and the Russian Empire. ${ }^{28}$

While substantiating the principle that civil rights are absolute and inalienable, representatives of the "revived natural law" school also developed a model of the relationship between the individual and public authority. They argued that the individual is vested with autonomy, the right of privacy, and the guarantees of state protection in case of violation of his or her rights and liberties. Public authority's obligation of non-interference in individual freedom means that the individual has the right to such non-interference, a right that can be defended in court. According to Vladimir Gessen, an eminent supporter of the natural law revival, the following principle was in force for the individual: "Everything which is not forbidden by law is permitted." A different principle applied for the authorities: "Everything which is not permitted by law is forbidden." 29

\section{The concept of subjective public rights}

The concept of subjective public rights served the purpose of consolidating civil rights theory in state (constitutional) law. This concept was created by the German legal scholars Rudolf von Ihering and Georg Jellinek. As Jellinek argued, subjective public rights were something that citizens could demand for themselves from the state. Thus they were not limited to the "passive status" (status passivus) that Jellinek identified as their basic status, the status of subjects entirely submitted to the state's authority. Jellinek postulated the priority of the individual's public rights and claimed that the state should refrain from any actions that might prevent the individual from exercising his or her freedoms..$^{30}$

Russian jurists were influenced by this concept and developed it further. In the "revived natural law" theory, the notion of "subjective public rights" was widely used. One of the most comprehensive definitions of subjective public rights was given in 1907 by Sergei Kotliarevskii, an expert on state law. For Kotliarevskii, this

28. Walicki, Legal Philosophies of Russian Liberalism, 367.

29. V.M. Gessen, Administrativnoe pravo [Administrative law] (SPb.: Tipografiia M.M. Stasiulevicha, 1903), 27; V.M. Gessen, O pravovom gosudarstve [On the rule-of-law state] (SPb.: Izdanie N. Glagoleva, 1906), 24-26.

30. Georg Jellinek, The Declaration of the Rights of Man and of Citizens: A Contribution to Modern Constitutional History (New York: Holt, 1901), 6, 28 (originally published in 1895 as Die Erklärung der Menschen- und Bürgerrechte); Georg Iellinek [Georg Jellinek], Obshchee uchenie o gosudarstve [General doctrine of law] (SPb.: Iuridichesky Center Press, 2004, originally published in 1903), 406. See also: Rudolf von Ihering, "Law as a Means to an End," in Modern Legal Philosophy Series, vol. V. (Boston: The Boston Book Company, 1913, translated from the German by Isaak Husek): 66-67, 108, 242. 
notion meant that each member of a state has a certain sphere of life and activity that is protected from encroachment by the authorities ${ }^{31}$ Russian jurists working during the great constitutional reforms were both theoretically and practically minded and were intent on applying this notion concretely. Therefore, when speaking about the subjective public rights of the individual, they meant that the existence of a rule-of-law state was a condition for their implementation. Kistiakovskii, for instance, pointed to the inviolability of subjective public rights in a rule-of-law state deprived of the opportunity to restrain or violate these rights. ${ }^{32}$

In his book written in 1906, Gessen also connected the category of subjective public rights with a rule-of-law state in which the individual becomes a subject of public rights and duties, i.e., a citizen (grazhdanin), while in a police state, which aims at total control over the lives of its subjects, the individual is only an object of authority, i.e., a subject (poddannyi). ${ }^{33}$ The elaboration of the theories of subjecthood (poddanstvo) and citizenship (grazhdanstvo) and the identification of the essential differences between a subject (poddannyi) and a citizen (grazhdanin) are some of this scholar's considerable achievements. Gessen used the term subjecthood (poddanstvo) to denote that the individual belongs to the state, and the term citizenship (grazhdanstvo) to convey that people are equal members of civil society in an ideal state where everyone "is a subject of a certain category of rights, notably political rights." ${ }^{34}$ Following the Kantian das Sein and das Sollen theory, Gessen found citizenship (grazhdanstvo) an ideal that ought to be (das Sollen), while subjecthood (poddanstvo) was the existing reality (das Sein). He argued that Russian legislation, institutions, and traditions could serve as matrices for the evolutionary transition from subjects (poddannye) deprived of rights to citizens (grazhdane) vested with rights. Gessen's attempt to place rights at the core of the concept of citizenship, in contrast to the political and legal reality existing in Russia, where duties towards the state union prevailed, was one of his major intellectual accomplishments. He claimed that the individual could not be secondary in relation to the state and its laws, and that civil rights were of a universal nature. ${ }^{35}$

The Russian representatives of the "revived natural law" school used the theory of the individual's three statuses that Georg Jellinek developed to show how the initial "passive status" had been historically overcome. Jellinek posited that the development of individualism in the course of the transformation of relations between the individual and the state throughout history was continuous and progressive.

31.S.A. Kotliarevskii, Konstitutsionnoe gosudarstvo: Opyt politiko-morfologicheskogo obzora [The constitutional state: A political and morphological review] (SPb.: Izdanie G.F. L'vovicha, 1907), 80.

32. Kistiakovskii, Prava cheloveka i grazhdanina, 117.

33. Gessen, O pravovom gosudarstve, 23-24.

34. V.M. Gessen, Poddanstvo: Ego ustanovlenie i prekrashchenie [Subjecthood: Its establishment and cancelation], vol. 1 (SPb.: Pravda, 1909), 116.

35. Eric Lohr, "The Ideal Citizen and the Real Subject in Late Imperial Russia," Kritika: Explorations in Russian and Eurasian History, 7, 2 (2006), 182. 
He interpreted the negative status of rights (status negativus) as the individual's free self-determination and expression of will (free from interference on the part of the state). Among negative status rights, he included freedoms born in the course of the struggle with official repression, such as freedom of conscience and of the press, the security of private residence, and the right to meeting and assembly. He saw the positive status of rights (status positivus) as one that provided its bearers with claims for the state to act on their behalf. In Jellinek's classification, the active status (status activus) was closely connected with the positive status; it allowed the individual to become involved in society and exercise his or her public rights as guaranteed by law. The positive status outlined the area of potential activity, while the active status was a sphere for exercising civil legal capacity. The active status of rights included, for example, the right to participate through election in the work of state bodies. ${ }^{36}$

Following Jellinek, Russian natural law revivalists determined a universal set of civil rights and freedoms and worked out their classification. One of the most comprehensive and logically coherent Russian versions of the catalogue of rights was created by Vladimir Gessen. He singled out three categories of subjective public rights. The first one included the rights of freedom (prava svobody). By guaranteeing these rights, the state authority recognized that a citizen had a certain sphere of freedom in which it was not to interfere ("negative status rights"). Gessen's view on this category of rights was close to Jellinek's. Under authoritarian regimes, these rights are most severely trampled on by the state power, while constitutional states protect them and proclaim them to be the integral rights of the individual and the citizen. This category included basic civil freedoms guaranteed by declarations of rights and constitutions, such as the freedom of belief, speech, press, meeting, assembly, travel, trade, occupation and others. The second category of rights, i.e., the positive public rights of the individual or the rights to services from the state authority, included the rights to judicial protection (the right to sue), social protection (social welfare), and education ("positive status rights"). By active status rights, the legal philosopher meant the rights to implement government (political rights): the active and passive right to vote, the hereditary right to membership in the upper chamber, the right to be elected to the Chamber of Deputies, the right to be a juror, etc. ${ }^{37}$ When compiling his catalogue, Gessen took Jellinek's into consideration. However, Gessen gave a more detailed and comprehensive definition of negative status rights and their types. Thus, he included the freedom of movement (svoboda peredvizheniia) and occupation (svoboda zaniatii), which were not fully guaranteed for peasants. He also highlighted the role of the state in granting individual rights and freedoms. The state Gessen had in mind was

36. Iellinek, Obshchee uchenie o gosudarstve, 406-408; E.B. Levental', "Vklad Georga Iellineka v razvitie instituta osnovnykh prav i svobod [Georg Jellinek's contribution to developing the institution of basic rights and freedoms]," Pravo i politika, no. 2 (2007): 75-83.

37. V.M. Gessen, Osnovy konstitutsionnogo prava [Fundamentals of constitutional law] ( $\mathrm{SPb}$.: Izdanie iuridicheskogo knizhnogo sklada "Pravo," 1918), 87-89. 
the authoritarian Russian state he lived in, which had a prospect for transformation into a constitutional state after 1905 .

While Gessen considered the rights and liberties of every category to be equally important, Kistiakovskii ranked them in order of significance. He claimed that the most essential right of the individual was the right of personal inviolability, and also the right of inviolability of home and correspondence; without them, all other civil rights seemed illusive. In a rule-of-law state, personal inviolability was protected by the bodies of state power, which acted within strict legal boundaries. Kistiakovskii analyzed how the catalogues of rights in the legislations of European countries (England, France, Germany) and the US expanded and found an important trend in the development of subjective rights: their transformation from national rights into the universal rights of the individual and the citizen. ${ }^{38}$

Russian natural law revivalists also actualized the positive rights concept. A package of new social rights was included in the concept of the right to a dignified life (pravo na dostoinoe chelovecheskoe sushchestvovanie) developed by Vladimir Solov'ev at the end of the nineteenth century. Solov'ev understood it as the right of any individual to have secure means of subsistence and sufficient physical rest, which provided conditions for spiritual improvement. ${ }^{39}$ Novgorodtsev made a considerable contribution to the development of this concept. He interpreted the right to a dignified life extremely broadly, as the possibility of a dignified life guaranteed by the state to people suffering from economic dependence, lack of money, and unfavorable life circumstances. Inclusion of the right to a dignified life in the declaration of rights, in Novgorodtsev's opinion, led to such juridical consequences as the recognition of the right to social security in case of illness, disability and old age for every worker; the recognition of the right to work; the recognition of the right to a certain standard of living; the recognition of the right of individuals united by common interests and mutual support to form trade unions; and the recognition of the rights of helpless and disabled people to obligatory government and non-government care. Novgorodtsev considered factory laws to be a mechanism for implementing the right to a dignified life, and he believed that their purpose was to protect the interests of working people by guaranteeing them the right to social security in case of illness, old age and disability, by regulating working conditions, etc. ${ }^{40}$

Novgorodtsev suggested including statements about recognizing the right to a dignified life, to work, and to the normal application of labor in the program of the Constitutional Democratic (Kadet) Party, of which he was one of the founders. Later on, these issues were discussed in the Juridical Council of the Provisional

38. B.A. Kistiakovskii, Filosofiia i sotsiologiia prava [Philosophy and sociology of law] (SPb.: Izd-vo Russkogo khristianskogo gumanitarnogo instituta, 1999), 545.

39. V.S. Solov'ev, Pravo i nravstvennost': Ocherki iz prikladnoi etiki [Law and morality: Essays on applied ethics] (SPb.: Izd-vo Ia. Kantorovicha, 1899), 20.

40. P.I. Novgorodtsev, "Pravo na dostoinoe chelovecheskoe sushchestvovanie [The right to a dignified human existence]," in Sotsial'no-filosofskie etiudy P.I. Novgorodtseva $i$ I.A. Pokrovskogo [Social and philosophical essays by P.I. Novgorodtsev and I.A. Pokrovskii] (SPb. - M.: Izd-vo Tovarishchestva M.O. Vol’f, 1911), 5-6. 
Government, while the declaration of rights for the future constitution was being prepared for the Constituent Assembly. Novgorodtsev's ideas about the right to social security in case of illness and disability were further developed in the bills "On social security for workers in case of illness" and "On insuring workers against accidents," which were introduced by P.A. Stolypin's government into the State Duma in 1908. The workers' right to professional self-organization that Novgorodtsev advocated was secured in the Decree on Societies and Unions of 4 March 1906.

Novgorodtsev did not see any serious contradiction between classical civil rights and new social rights. However, he warned against dangerous destructive illusions, such as the idea of establishing paradise on earth, which, in his opinion, could be caused by the struggle of Russian revolutionaries for social rights. ${ }^{41}$ This legal philosopher was one of the first to speak of the dangers associated with radical utopian ideologies that had the potential for mastering minds and claiming the status of the only true ideology, which was particularly topical for the twentieth century.

Meanwhile, Kistiakovskii was led by his theoretical concept of public-legal subjective rights to the idea of a socialist state as a new and higher stage of the rule-of-law state. He argued that the task of this state was to broaden the sphere of subjective public rights, which, in his opinion, would significantly change the position of citizens in the country and make them enjoy full rights. As the jurist predicted in his famous article in the Vekhi collection, only in a socialist state would all the members of society possess the greatest degree of freedom of activity and self-determination, and would political bodies get an exact legal formulation. ${ }^{42}$ Kistiakovskii prophetically suggested that the socialist state would develop the right to work (interpreted as the right to use the land and other means of production), the resulting right to develop one's abilities and apply one's labor to the sphere best corresponding to those abilities, and the right to participate in the material and spiritual values created by culture. He subsumed these rights under what he called the "right to a dignified life" (pravo na dostoinoe chelovecheskoe sushchestvovanie), which was to be guaranteed to every person and provided by the state. It is evident that the jurist's ideas of the socialist state were purely theoretical and highly idealized. In his other works, he called a state that protected the joint interests of people and the common good a "socially oriented state" (sotsial'noe gosudarstvo)..$^{43}$ The natural law revivalists were credited for the catalogue of human rights and freedoms and the elaboration of a system of subjective public rights. Developing the theory of subjective public rights in early twentiethcentury Russia during the expanding movement for legislative guarantees of civil

41. Walicki, Legal Philosophies of Russian Liberalism, 328.

42. B.A. Kistiakovskii, "V zashchitu prava (Intelligentsiia i pravosoznanie) [In defense of law (Intelligentsia and legal consciousness]," in Vekhi: Sbornik statei o russkoi intelligentsii [Landmarks: A collection of articles about Russian intelligentsia] (M.: Tipograpfiia Sablina, 1909), 113.

43. Kistiakovskii, "Sotsial’nye nauki i pravo...," 543-545. 
rights, which was led by liberal social activists through their publications, organizations and other institutions, Neo-Kantians were in a hurry to transform natural rights from the "das Sollen" category to the "das Sein"; in Kistiakovskii's words, they tried "to pass from theory to practice, from examining the theoretical meaning of subjective public rights and their system to recognizing them in legislation and implementing them in reality." 44

\section{"Freedoms will be permanent in Russia only when they are guaranteed"}

Kistiakovskii, who delivered a course of lectures on state law in the 1908-1909 academic year, claimed that in order to make civil freedoms formal and juridical, "it is not sufficient to have only laws on freedoms; we also need good laws on the responsibility of officials." These laws will give any citizen whose subjective public right is violated an opportunity to initiate a criminal or civil action against the official who violated it by advancing a claim for damages. ${ }^{45}$

The civil rights theory of the natural law revivalists was fully developed thanks to the system of guarantees of rights elaborated by its representatives. The theorists of the "revived natural law" school believed that the protection of subjective rights and the creation of conditions for their implementation were the basic function of the rule-of-law state. They formulated a system for guaranteeing these rights. They interpreted the state's ability to secure the rights of its citizens as a sign that the state was restricted by law, that it was governed by law. By contrast, they did not consider a state in which public authority could abolish basic rights and freedoms at its sole discretion to be governed by law. Kistiakovskii wrote:

These freedoms are an inalienable right for every individual, so that the state system in which they are violated cannot be considered normal [...]. Where these freedoms do not exist or [...] can be abolished at least temporarily [...], the state authority is violent and not law-based by nature. ${ }^{46}$

The natural law revivalist theorists associated the establishment of the system of guarantees of civil rights with the introduction of the constitutional system in Russia. They joined a discussion on the significance of the 1905-1906 state reform, whose main landmarks were the adoption of the Manifesto of 17 October 1905, which proclaimed that people were granted civil freedoms and a representative body, and the publication of a new edition of the "Fundamental Laws (Osnovnye

44. Kistiakovskii, "Gosudarstvennoe pravo (obshchee i russkoe)...," 204.

45. Ibid., 247.

46. B.A. Kistiakovskii, Sushchnost' gosudarstvennoi vlasti [The essence of state power] (Yaroslavl’: Tipografiia Gubernskogo pravleniia, 1913), 474, 479; Id., Filosofiia i sotsiologiia prava, 328. 
zakony) of the Russian Empire" of 23 April 1906, which contained a chapter on civil and political rights.

Jurists divided into two camps in their assessment of the legal significance of the above-mentioned acts. The first camp was comprised of skeptics who did not recognize the Manifesto of 17 October as an act that introduced a new legal system. They interpreted it as merely a declaration of the supreme authority's intentions to transform the Russian state system on the basis of the rule-of-law state. Thus, Moscow University Professor of State Law Fedor Kokoshkin described the Manifesto as an act that introduced no significant changes into Russian state law; it "just showed the way for the reform to go." ${ }^{47}$ Another part of the legal community identified the Manifesto with the Constitution. Kistiakovskii became convinced that the 1905-1906 reform in Russia introduced a constitutional system as well as subjective public rights for citizens.

In Russia, before the 1905-1906 state reform, the individual did not have any subjective rights in relation to the state. [...] This led [...] to the suppression of individual rights by the state and the authorities. That is why we can speak about the "rights of man and of the citizen" only beginning with the Manifesto of 17 October $1905 .{ }^{48}$

The system of civil right guarantees created by Russian legal thinkers at the beginning of the twentieth century did not differ very much from the three types of subjective right guarantees formulated by Georg Jellinek. Jellinek distinguished social (he included here religion, morals, and social customs), political (separation of powers, local government, etc.), and legal guarantees (responsibility of ministers, impeachment, administrative justice, etc.). According to Jellinek, legal guarantees were primarily realized through the supervising function of the state, which exercised administrative, financial and parliamentary types of control. ${ }^{49}$

Russian natural law revivalists such as Gessen, Kotliarevskii, and others saw four ways - political, social, material and legal - of guaranteeing rights. According to them, political guarantees included separation of powers and the by-law nature of the judicial and administrative branches of power; social guarantees included the state of social mores, morals and the legal consciousness of the public; material guarantees included personal economic independence; and legal guarantees

47. F.F. Kokoshkin, "Iuridicheskaia priroda Manifesta 17 oktiabria, [The juridical nature of the October 17 Manifesto]," Iuridicheskii vestnik, no. 1 (1913), 43.

48. Kistiakovskii, Gosudarstvennoe pravo (obshchee i russkoe), 228, 231-233, 237, 246. See also Marc Szeftel's analysis of the controversy about the interpretation of the institutional change after the October Manifesto: Marc Szeftel, The Russian Constitution of April 23, 1906: Political Institutions of the Duma Monarchy (Bruxelles - Luxembourg: Les Éditions de la Librairie Encyclopédique, 1976), 202-211, 236-242, 264-66.

49. Iellinek, Obshchee uchenie o gosudarstve, 745-750. 
included administrative justice, constitutional supervision, and the responsibility of ministers and other officials before legislative and judicial powers. ${ }^{50}$

Vladimir Gessen's political conception was the most original and interesting among those of his colleagues from the "revived natural law" school as concerns the Russian case. It was a variant of the classical conception of the separation of powers created in the Early Modern period. It often employed the phrase "separation of powers" (obosoblenie vlastei), by which the author meant the precedence of the legislative branch over the executive branch and the adherence to law by the executive and judicial branches. This point was very significant for Russian executive and judicial powers during the constitutional reform in 1905 and 1906. According to Gessen, the separation of powers was a fundamental guarantee of subjective public rights, and a key indicator of the rule-of-law state. Gessen pointed out that in the rule-of-law state only the legislative power, which expressed the will of the people, was not restricted by the current law in carrying out its prerogatives. Adherence to law by the executive and judicial powers was a component of the state's self-restriction, since the state, by issuing a law, restricted not only subordinate individuals but also itself. Thus, both the state, represented by the executive power, and any citizen, dependent on it, were legal entities, i.e., bearers of objective obligations and rights. ${ }^{51}$

Following the lead of German jurisprudence of the second half of the nineteenth century, which assigned key positions in the system of legal guarantees of subjective rights to the judicial power, natural law revivalists developed a doctrine of administrative justice. Administrative justice was to play a key role in guaranteeing civil rights. Russian legal thinkers understood it as judicial control over the legality of acts issued by administrative bodies and protection of the citizen's right to bring a complaint to judicial authorities about the administration's actions.

In the theoretical developments of prerevolutionary legal scholars, the idea of administrative justice was a derivative of the principle of separation of powers exercised in the rule-of-law state. Thus, by "administrative justice," Gessen meant "a specific and separate organization of the judicial power designed to protect subjective public rights by cancelling unlawful orders of the executive power." 52 In theoretical disputes about the essence of administrative justice, the need for a special administrative court, and the transfer of supervision over the legality of administrative acts and decisions to courts of general jurisdiction, Gessen took a definitive stand. He supported the establishment of an independent judicial body to strike down any unlawful decree of the executive power. The investigation of a conflict between an individual and the authorities, arising from administrative law,

50. V.M. Gessen, "Teoriia pravovogo gosudarstva [Theory of the rule-of-law state]," in Politicheskii stroi sovremennykh gosudarstv [The political system of contemporary states] $(\mathrm{SPb}$.: Izd-vo kn. P.D. Dolgorukova i I.I. Petrunkevicha pri uchastii redaktsii gazety "Pravo," 1905), 140-143; S.A. Kotliarevskii, Vlast' i pravo: Problema pravovogo gosudarstva [Power and law: The rule-of-law state issue] (M.: Tipografiia "Mysl"”, 1915), 287-288.

51. Gessen, O pravovom gosudarstve, 12.

52. Gessen, Osnovy konstitutsionnogo prava, 90-91. 
demanded from the judge, in the scholar's opinion, a special - administrative, but not private-law - knowledge, which meant that an ordinary civil court could not be charged with this task. ${ }^{53}$ Describing the status of administrative courts, Gessen claimed that they should rest upon the following important principles: independence of administrative judges from the administration (as was the case with civil judges), irremovability of judges, the collective nature of the court, and adversarial, public legal proceedings. Gessen called this type of administrative justice "the Archimedean lever of the rule-of-law state." 54

In the juridical literature of that time, as well as in today's works on Russian administrative law, the concept of administrative justice as a special form of judicial power was not generally recognized. The German jurist Rudolf Gneist, for instance, believed that administrative justice was a continuation of administrative power and was intended for its self-control..$^{55}$ British jurists rejected the notion of administrative justice. Albert Dicey, for example, was of the opinion that, if problems related to administrative functioning were to be settled by a special jurisdiction, it would take them out of the general court system and give an advantage to the state over individuals. ${ }^{56}$ Meanwhile, Russian legal theory considerably outstripped the institutionalization of administrative justice. In 1917 the Provisional Government's project to create special administrative courts was based precisely on the concept of administrative justice developed by Russian natural law revivalists. ${ }^{57}$

One of the most widely discussed issues in the early twentieth century among legal scholars was the expedience of introducing an institution for constitutional supervision with the power of judicial review. Sergei Kotliarevskii took an active role in this discussion. The activity of the US Supreme Court, which reviewed the constitutionality of laws and had a great impact on constitutional development in the US, was a positive example for him. According to him, the very possibility of verifying a law's compliance with the fundamental law provided a guarantee against the violation of the constitution by the legislature. ${ }^{58}$

Russian legal thinkers also considered that instituting responsibilities for ministers and other officials was a legal guarantee of individual rights. They considered that the responsibility of ministers to the parliament, that is, the responsibility of the executive power to the legislative power, was a guarantee of adherence to law by

53. Gessen, $O$ pravovom gosudarstve, 46.

54. Gessen, Teoriia pravovogo gosudarstva, 141.

55. Rudolf Gneist, Istoriia gosudarstvennikh uchrezhdenii Anglii [History of state institutions in England] (M.: K.T. Soldatenkov, 1885, originally published in Germany in 1882 as Englische Verfassungsgeschichte), 762-776.

56. Albert Dicey, "The Development of Administrative Law in England," Law Quarterly Review, 31 (1915): 151-153.

57. E.A. Pravilova, Zakonnost' $i$ prava lichnosti: administrativnaia iustitsiia v Rossii (vtoraia polovina XIX v. - oktiabr' 1917 g.) [Legality and individual rights: Administrative justice in Russia (second half of the nineteenth century - October 1917] (SPb.: Izd-vo SZAGS, 2000), 251.

58. Kotliarevskii, Vlast' i pravo, 287-288. 
the governmental power in rule-of-law states. According to Gessen, constitutional ministries were to be accountable to the monarch and parliament. ${ }^{59}$ The Russian experience of a Duma-ruled monarchy confirmed the validity of the jurists' position that the accountability of ministers to the representative body was the key statement of the constitutional state. ${ }^{60}$

Kotliarevskii, like Gessen, ranked the protection of civil rights in court first among the guarantees of civil rights in a constitutional state. ${ }^{61}$ The responsibility of ministers to the people for their violations of law ranked second. Kotliarevskii considered the state of society's juridical consciousness to be no less significant a guarantee of individual rights and freedoms. In his opinion, the system of guaranteeing subjective rights was effective only "if the whole nation was aware of the importance of these individual rights, of the great danger coming from the violation of the rights by the state authority, and was ready to protect them." ${ }^{\prime 2}$

In his statement of the question about the legal consciousness of society as a condition for the insurance of subjective rights, Kotliarevskii was a true exponent of the position of the "revived natural law" school, which considered legal consciousness to be the source for the development of law and statehood. This position was a result of the natural law school's general views on the sources of law. Kistiakovskii thought that the main problem in Russia was the intelligentsia's lack of a firm legal consciousness, nihilistic attitude to objective law and order, and indifference towards individual rights, as well as to institutions that protected them (such as civil courts, popular representation, etc.). In his famous article in Vekhi, the scholar wrote:

The Russian intelligentsia consists of people who are not disciplined, either individually or socially. This is explained by the fact that the Russian intelligentsia has never respected law, has never seen it as valuable; of all cultural values law has always been the least recognized. ${ }^{63}$

Novgorodtsev considered legal consciousness to be the source and roots of life in the state. He regarded social legal consciousness, which included people's moral consciousness and moral ideas about the state and state order, as a key factor for

59. Gessen, Teoriia pravovogo gosudarstva, 142-143; Id., Osnovy konstitutsionnogo prava, 393, 396-397.

60. Lack of responsible government is considered by researchers to be one of the most vulnerable spots of the Russian Duma monarchy: K.A. Solov'ev, Zakonodatel'naia i ispolnitel'naia vlast' v Rossii: mekhanizmy vzaimodeistviia (1906-1914) [Legislative and executive power in Russia: Mechanisms of interaction] (M.: Rossiiskaia politicheskaia entsiklopediia, 2011), 136-140; I.V. Lukoianov, $U$ istokov rossiiskogo parlamentarizma [The sources of Russian parliamentarism] (SPb.: Liki Rossii, 2003), 81.

61. For Kotliarevskii, rule-of-law state and constitutional state were not synonymous. He considered that the rule-of-law state was an idea that did not apply in Russian conditions.

62. Kotliarevskii, Konstitutsionnoe gosudarstvo: Opyt politiko-morfologicheskogo obzora, 99-100.

63. Kistiakovskii, "V zashchitu prava,” 102. 
exercising subjective rights, and for the consolidation and recognition of these rights by the legislature. ${ }^{64}$

Legal consciousness was the core of Ivan Il'in's philosophy. In a report at the meeting of the Moscow Juridical Society in 1916, Il'in said that the essence of normal legal consciousness (in his later works he wrote about mature natural legal consciousness as an ideal type of legal consciousness) consisted not only in exact knowledge of positive law but also in independent, autonomous recognition of its objective importance, and also in the will to establish a social organization based on freedom, equality and self-government. According to Il'in, the spread of normal legal consciousness was supposed to contribute to bringing positive law nearer to natural law and gradually make positive law unnecessary. ${ }^{65}$

Thus, the doctrine of the guarantee of rights, which was developed by the Russian theorists of the "revived natural law" school in the early twentieth century, drew on the ideas of German thinkers of the second half of the nineteenth century on the essence of the guarantees of subjective rights, and reflected the Russian experience of building a rule-of-law state, as well as ensuring the rights of the individual in a state that was undergoing a transition from the authoritarian to the rule-of-law type.

\section{The influence of the natural law doctrine on the elaboration of new legal forms}

When he explained the reasons for reviving natural law, Pavel Novgorodtsev noted a connection between the natural law doctrine and the creation of new legal forms and pointed to the urgent need that invariably leads to natural law schemes. He called it the need to "go towards the future and realize [...] ideal aspirations and hopes in it." According to the philosopher, this need was most evident in periods of crisis, when old forms of life proved to be obsolete, and society felt an insatiable desire for a new order. This desire for something new generated "a constant dissatisfaction with existing law which hasn't changed yet" and "a demand for better, ideal, natural law." ${ }^{66}$

As the Russian form of government evolved towards a constitutional one, the ideas of the "revived natural law" school set the direction of law reform and its theoretical content. The individual freedoms issue came to the foreground in jurisprudential literature with the publication of the Manifesto of 17 October 1905, which declared civil freedoms. The ideas and values of human rights were expressed in scientific and journalistic works written by members of the liberal professoriate who were sympathetic to the demand for civil liberties and saw their task as explaining

64. P.I. Novgorodtsev, "Pravo i gosudarstvo [Law and State]," Voprosy filosofii i psikhologii, no. 74, 4 (1904): 535.

65. "V iuridicheskom obshchestve [In a law society]," Russkie vedomosti (14 December 1916): 6.

66. Novgorodtsev, "Nravstvennyi idealizm v filisofii prava,” 250. 
their significance to the society. Law professionals, such as Vladimir Gessen, Pavel Novgorodtsev, and Bogdan Kistiakovskii played a key role in the development of the constitutional movement seeking to advance legal protection of civil rights. They worked in legal societies ${ }^{67}$ gave lectures on comparative state law, and translated constitutional classics published in the West (for instance, Kistiakovskii translated G. Jellinek's Constitutions, their changes and alterations and wrote an introduction to it $^{68}$ ).

The ideas of liberal transformation of political and legal life in Russia were suggested in the legal periodicals Pravo, Vestnik Prava, Iuridicheskii Vestnik and others, and collections of articles, ${ }^{69}$ to which Novgorodtsev, Kistiakovskii, Evgenii Trubetskoi, Vladimir Gessen, and other eminent Russian legal scholars contributed. Vladimir Gessen and Nikolai Lazarevskii were editors of the newspaper Pravo. The liberal jurists Iosif Gessen, Leon Petrażycki, Avgust Kaminka and Vladimir Nabokov took an active part in publishing this newspaper, which paid considerable attention to the issue of individual rights and their guarantees, and to the discussion of the bills of rights proposed by the Duma and the state.

A democratic "revolution" took place in 1905 and 1906 in civil legal education and in legal consciousness on the whole. Michel Tissier has concluded that after 1905, civil education was aimed at popularizing civil rights, while before 1905 only existing law was popularized. Tissier re-examines early twentieth-century debates about the Russians' allegedly insufficient legal consciousness and argues that legal consciousness became understood in Russian intellectual thought in 1905 and 1906 not in connection with law in the form of legislation, jurisprudence and customary law, but in relation to the idea of the existence of individual inalienable rights, their inclusion in the positive law of the Russian Empire and their unconditional application. ${ }^{70}$ William Pomeranz, a scholar of the legal culture of the Russian bar (advokatura), points to the formation of an advanced legal culture and professional ethos in the advokatura between 1864 and 1917, and to the appearance of many outstanding advocates of civil rights in the legal profession..$^{71}$ The concept of the rule of law was accepted by educated society.

67. See Michel Tissier, "Les sociétés juridiques dans l'Empire russe au tournant du xx ${ }^{\mathrm{e}}$ siècle: professionnalisation des juristes et culture juridique," Cahiers du Monde russe, 51, 1 (2010): 5-34.

68. G. Iellinek [G. Jellinek], Konstitutsii, ikh izmeneniia $i$ preobrazovaniia, perevod $s$ nemetskogo pod redaktsiei $i$ so vstupitel'noi stat'ei B.A. Kistiakovskogo [Constitutions, their changes and alterations, translation from German, editing and introduction by B.A. Kistiakovskii] (SPb.: Izdanie Iuridicheskogo knizhnogo sklada "Pravo", 1907).

69. Konstitutsionnoe Gosudarstvo: Sbornik statei Kistiakovskogo [Constitutional State: Selected papers by Kistiakovskii] (M.: Izdanie I.V. Gessena, A.I. Kaminka, 1905); Politicheskii Stroi Sovremennykh Gosudarstv Kistiakovskogo [The Political Systems of Contemporary States by Kistiakovskii], vol. 1 (SPb: Izd-vo P.D. Dolgorukogo i I.I. Petrunkevicha pri uchastii redaktsii gazety "Pravo," 1905).

70. Tissier, "Kakoe iuridicheskoe prosveshchenie nuzhno Rossii?" 60-62.

71. William Pomeranz, "Profession or Estate'? The Case of the Russian Prerevolutionary 'Advokatura," The Slavonic and East European Review, 77, 2 (1999): 240-268. 
Liberal theory gave an impulse to the formation in the twentieth century of liberal parties, which included in their programs the ideas of human rights, civil equality and supremacy of law. As Novgorodtsev pointed out, the idea of natural law had found its place among the political ideas of Russian progressive parties, first of all the Kadet party, before contemporary jurists started speaking of it. ${ }^{72}$ Pavel Novgorodtsev, Vladimir Gessen, Bogdan Kistiakovskii, Evgenii Trubetskoi and other representatives of "the revived natural law" school, alongside judicial positivist Gabriel' Shershenevich and the leader of the sociological theory of law Nikolai Gredeskul, became Kadet theorists. They significantly contributed to the formation of the legal ideology of the liberal movement, which consolidated under the slogan of realizing individual rights and freedoms, and motivated the Russian government to guarantee subjective rights by law in 1905 and 1906. Their political ideal was the rule-of-law state, based on people's representation in the state bodies, a government accountable to the Parliament and an independent court.

The civil rights theory favored the formation and development of parliamentarianism in late imperial Russia. The State Duma became a social medium for discussing the content of civil rights and for developing appropriate bills, and also for organizing control over the enforcement of subjective rights by the executive power. The Kadet faction introduced bills of personal immunity, freedom of conscience, assembly, unions, and press, and the fundamental provisions of civil equality laws to the First Duma. Their authors were Novgorodtsev, Kotliarevskii, Gessen and other jurists. They worked within the legislative committee of the Kadet party, which was divided after the First Duma into the Moscow and St. Petersburg departments. Novgorodtsev, Kotliarevskii, Shershenevich and others, who joined the Moscow department, focused on the projects on universal suffrage and civil equality, enriching them with statements about the abolition of estate, national and confessional differences.

Elaborating on the content of legal reforms, supporters of the new natural law ideology proclaimed a new view of law. They interpreted it not as an order of state power, but as "an independent force directing and creating different forms of private and public life." "73 The theorists of the school believed that law was not established by the legislator, but was a manifestation of society's legal consciousness. They made efforts not only to reveal this legal consciousness, but also to influence it. Jurists wrote about the critical state of legal consciousness during the revolutionary period, which manifested itself in a glaring discrepancy between positive law and the public ideal. Novgorodtsev saw the roots of the crisis in legal consciousness in the increasing gap between positive law and the moral foundations of public life. He understood the history of law as a history of constant changes in law. According to Novgorodtsev, law could only renew itself by rejecting its past; the scholar used

72. Novgorodtsev, Nravstvennyi idealizm v filosofii prava, 595.

73. B.A. Kistiakovskii, "Nashi zadachi [Our objectives]," Iuridicheskii vestnik, no. 1 (1913): 9,15 . 
the metaphor of "Saturn devouring his own children." In the course of the emerging conflict, natural law was born as a demand for changes in the existing order and as an ideal plan for public reorganization.

Analyzing the legislative activities of the First Duma, Novgorodtsev saw that his suppositions about the need for profound legal reforms were confirmed. He wrote:

When we set new principles stemming from the general demands for a rule-of-law state, we immediately discovered that these principles ran up against our old laws, built on absolutely different principles. We had to build on ground that was interwoven with old and widely spread roots. When attempting to abolish one set of laws, we immediately discovered that we had to think about abolishing or changing many other laws connected with it. And inspired by the idea which took us forward, we embarked on this difficult and enormous work whose completion meant changing the whole Russian legal system. ${ }^{74}$

Advocating wide-scale legal reforms aimed at creating a rule-of-law state, scholars came to the conclusion that it was impossible in Russia at that time. They saw the main reason for this in the state of legal consciousness and power. Nikolai Lazarevskii wrote:

If the majority of the population does not know anything about its rights; if, accustomed to laws being broken, it looks upon this violation as something ordinary and inevitable; if for centuries the population has been used to being totally dependent upon the administration; [...] if, on the other hand, administrative bodies haven't yet realized that a common man may have rights, inviolable by an official [...]; then in such a society the unconditional promotion of legality is practically impossible. ${ }^{75}$

Jurists saw a way out of this situation in the collapse of the old regime and the establishment of a constitutional order. They suggested implementing their ideal with the help of a Constituent Assembly (Uchreditel'noe sobranie). Jurists ranked the vesting of rights and freedoms among the most important reforms which were to be carried out before the convocation of the Constituent Assembly and elaboration of the Constitution. This means that individual rights were supposed to become a leading force in changing the people's legal consciousness in order to make them convinced of the supremacy of law and legality.

74. P.I. Novgorodtsev, "Zakonodatel'naia deiatel'nost Gosudarstvennoi Dumy [The legislative activities of the State Duma]," in Pervaia Gosudarstvennaia Duma [The First State Duma] (SPb.: Izdanie M.V. Pirozhkova, 1907), Issue 2, 11.

75. N.I. Lazarevskii, "Zakonnost' i predely ee osushchestvleniia [Legality and the limits of its implementation]," Pravo, no. 2 (1905): 71. 


\section{The positivists' interpretation of civil rights}

While the complex theory of civil rights and freedoms was created around the turn of the twentieth century by Russian legal scholars belonging to the "revived natural law" school, the problem of civil rights attracted the attention of representatives of other trends of legal thought; namely, theorists of Judicial Positivism and Sociological Jurisprudence.

Positivist legal theory took shape as a consistent criticism of natural law theory and the dualism between positive and natural laws that characterizes it. One of its most prominent theorists was Gabriel' Shershenevich, a professor of law at Moscow University and member of the Central Committee of the Kadet Party. Shershenevich argued that there is only one "true law" and that the notion of natural law should be discarded. He believed that the goal of the general theory of law was to define positive law. ${ }^{76}$

The doctrine of the main opponents of the natural law revivalists, which was developed by the Russian school of Judicial Positivism and represented by Gabriel' Shershenevich, Veniamin Khvostov, Semen Pakhman, and others, did not attach crucial importance to civil rights. For them, civil rights were granted by the state and fixed by laws issued by the state. The doctrine of judicial positivism vested the state with the function of creator of civil rights: the state determined the content and scope of civil rights, enforced them, and, if necessary, took unpopular measures aimed at restricting the rights of its citizens. Positivists rejected the possibility of limiting the prerogatives of state power by means of civil rights, interpreting this as self-restriction on the part of the state..$^{77}$

Meanwhile, Shershenevich and other liberal positivist jurists thought that the task of the contemporary monarchical state was to encourage self-action by Russian citizens by granting them civil and political freedoms and recognizing the principle of the equality of citizens before the law. Considering the state to be the source of law and subjective rights, they interpreted it in the spirit of the liberal legal tradition and saw its task as conferring individual rights and freedoms and protecting them in every possible way. They believed that a state capable of protecting the rights of its citizens was strong and efficient, while a state incapable of ensuring civil rights was doomed to weaken and make people doubt whether such a public-law institution was necessary. ${ }^{78}$

The liberal positivists paid considerable attention to fundamental freedoms, in particular to freedoms of speech and press, which, in their view, were the basis for positive public opinion, the latter being the guarantor of the strength of the state

76. G.F. Shershenevich, Obshchaia teoriia prava [General theory of law] (M.: Izd-vo brat'ev Bashmakovykh, 1911), 273.

77. V.D. Zor'kin, Pozitivistskaia teoriia prava v Rossii [The Positivist theory of law in Russia] (M.: Izd-vo Moskovskogo universiteta, 1978), 65; G.F. Shershenevich, Obshchaia teoriia prava [General theory of law], third edition (M.: Izd-vo brat'ev Bashmakovykh, 1912), 609.

78. G.F. Shershenevich, Obshchaia teoriia prava (M., 1909-1910), 368. 
and legal order. The freedom of meeting and assembly also ranked high, as it guaranteed the right to the development of political and cultural life. ${ }^{79}$ The theorists of Judicial Positivism formulated legal guarantees for the observance of civil rights. ${ }^{80}$ Thus, there is no denying the fact that the theory of civil rights was further developed in this teaching.

Unlike Judicial Positivism, which treated individual rights as conferred by the state, the theorists of Sociological Positivism considered individual rights to be a result of social development. The jurists of this school focused on the sociological approach to law, which presupposed defining legal issues in a wide social and historical context and in connection with the phenomena of public life. Thus, Sergei Muromtsev identified the emergence of a need for political freedom in post-reform Russian society. This need acquired the significance of a legal ideal and set the authorities the practical goal of procuring it:

The ideas of the inviolability of individual rights, freedom of thought and speech, and a state order that ensures these rights, have formed the basis for the ideal. [...] Society's endeavor to participate in the life of the state and its need for social activity have become facts that the government must take into account. [...] If the governmental mechanism [...] excludes [...] society's right to direct participation in state life [...], this mechanism is subject to reformation.

Muromtsev perceptively noted that the demand for civil rights is most acutely felt by educated society in the periods of radical social transformations ${ }^{81}$

Of particular interest is Muromtsev's idea that the dichotomy between law and justice creates an impetus for legal reform. This idea is close to Novgorodtsev's above-cited statement about the opposition of positive and natural law. Muromtsev interpreted law as the actual state and justice as a desirable state embodying an aspiration to an ideal. According to him, as negative attitudes towards existing law in society increase, positive ideals of justice are established, and, in turn, become an impetus for legal reform.$^{82}$ It was the formation of the positive ideal of justice that Muromtsev as chairman of the First Duma was dedicated to.

Nikolai Gredeskul, the representative of the sociological trend in law, wrote about the advantages of the sociological approach to law:

Under the domination of the dogmatics of law, the ideal jurist [...] is a "pushkinskii d'iak" (a clerk described by the Russian poet Pushkin) with a long

79. V.M. Khvostov, "Svoboda soiuzov i sobranii [Freedom of meeting and assembly]," Moskovskii ezhenedel'nik, no. 1 (1906): 9.

80. A. Rozhdestvenskii, Osnovy obshchei teorii prava [Fundamentals of the general theory of law] (M.: Izd-vo V.S. Spiridonova, 1912), 144-146.

81. S. Muromtsev, Statii i rechi (1878-1910) [Articles and speeches (1878-1910)] (M.: Tipografiia Obshchestva rasprostraneniia politicheskikh knig, 1910), 5, 21-22.

82. S.A. Muromtsev, "Pravo i spravedlivost" [Law and justice]" in Sbornik pravovedeniia $i$ obshchestvennykh znanii (SPb., 1903, vol. 2), 10, 12. 
experience of office work, looking quietly at those who are right and those who are guilty $[\ldots]$, who is always ready to solve the most complicated cases on the basis of current laws, while under sociological study, there appears an absolutely different ideal of the jurist [...]. This jurist is an arbitrator in the struggle of social classes, a creator of law; this is a jurist who informs the community on what the law should be like, who carries out this duty as an impartial scholar, independent from above and below. ${ }^{83}$

The theorists of sociological jurisprudence Maksim Kovalevskii and Nikolai Korkunov criticized the "revived natural law" theory for minimizing the role of the state and for its preferential attention to das Sollen and insufficient interest in das Sein. The supporters of the sociological approach to law pointed out the change of functions in the modern state in respect to the individual and individual rights as compared with the early modern state. They ascertained that the state which takes care of the protection of law (the rule-of-law state) is replaced by the state which cares for the common good (the social state). The latter infringes upon personal privacy and restricts individual freedom to secure freedoms for everyone ${ }^{84}$.

The basic postulates of Sociological Jurisprudence are as follows: civil rights appear as a result of the evolution of the state and society at a certain time and in certain conditions; the sphere of individual activity and the range of individual rights extend in accordance with the development of the state; certain stages in the development of society may be characterized by the constriction of the scope of individual rights and by strengthening control over them by the state. The institutions of the separation of powers, representation of people, local government, and the judicial protection of individual rights were recognized as guarantees for exercising civil rights. It was typical of the theorists of the sociological trend, as well as of the natural law revivalists, to recognize the priority of political rights in the system of human rights. They believed that political rights were first and foremost a condition for the legislative guarantee of rights and freedoms by the state and were in line with people's duty to participate in government. ${ }^{85}$

Despite the positivists' different interpretation of civil rights, they contributed to the creation of liberal legal doctrines which were aimed at the struggle for civil rights and freedoms, and for the consolidation of the rule-of-law state, whose

83. N.A. Gredeskul, Sovremennye voprosy prava [Contemporary legal issues] (Khar'kov: Izdanie knizhnogo magazina P.A. Breitigama, 1906), 14-15.

84. M.M. Kovalevskii, Sotsiologiia [Sociology], vol. 1 (SPb.: Tipografiia M.M. Stasiulevicha, 1910), 62; N.M. Korkunov, "Gosudarstvo i svoboda [State and freedom]," Iuridicheskaia letopis’' [Juridical chronicle], vol. 1 (1892), 5.

85. M.M. Kovalevskii, Obshchee konstitutsionnoe pravo: Lektsii, chitannye v S.-Peterburgskom universitete i Politekhnikume [General constitutional law: Lectures given at St. Petersburg University and Polytechnic school] (SPb.: Tipografiia "Sever," 1907-1908), 103-106; M.M. Kovalevskii, "Uchenie o lichnykh pravakh [The doctrine of individual rights]," Russkaia mys1', Book IV (1905), 102-103; Muromtsev, Stat 'i i rechi, $1^{\text {st }}$ ed., 64; $3^{\text {rd }}$ ed., 54; N.M. Korkunov, Russkoe gosudarstvennoe pravo [Russian state law], vol. 1 (SPb.: Knizhnyi magazin A.F. Tsinzerliga, 1892), 363-364. 
obligation was to grant freedoms and ensure their implementation. At the same time, it is obvious that the theorists of the "revived natural law" school had the most systematic approach to the institution of individual rights and freedoms. Kistiakovskii described the ideas of the supporters of the sociological theory and Juridical Positivism as suffering from the same shortcoming: "They are so intertwined with society and the state that they absolutely ignore the importance of individual autonomy." 86

\section{Conclusion}

Russian liberal jurists of the early twentieth century made a significant contribution to the development of ideas about law and the state, in general, and about positive and natural rights and the rule-of-law state in particular. A systematic theory of civil rights was formulated by the representatives of the "revived natural law" school. This theory became the basis for the doctrine of the rule-of-law state, which reconsidered ideas about the relationship between the individual and state authority in an authoritarian political regime. Russian jurists substantiated the claim that individual rights and freedoms were a significant institution in the rule-of-law state and that guaranteeing rights by law was a sign of and key element in building the rule-of-law state, with all its other features being subordinate.

The natural law revivalist theorists, relying on the key points of this scientific theory worked out by Russian and German legal philosophers, formulated the concept of subjective rights, which interpreted civil rights as natural and inalienable, belonging to the individual by right of birth. Within the framework of this theory, they developed the idea that individuals were autonomous in their relation to the state and that the state was forbidden from interfering with their individual liberty outlined both by natural law and positive law. Taking into account the specific features of the Russian political system, the Russian legal philosophers determined a hierarchy of civil rights and freedoms (negative status rights, such as personal inviolability and the right to meeting and assembly, being at the top of this hierarchy), and developed the idea of individual rights guarantees, such as administrative justice and the responsibility of ministers. The theory of subjective public rights laid the groundwork for the theory of citizenship, which was also actively developed by Russian legal scholars.

The key ideas created in Russian philosophy at the turn of the twentieth century (about inalienable civil rights and their protection from the state, the restriction of the state by law, the interdependence between law and the state of legal consciousness, about the inevitability of radical legal reforms, and about the separation of powers) had a truly revolutionary impact on the development of Russian legal thought. In the early twentieth century, legal theory developed on a wide ethical 
and pluralistic basis. Due to this, Russian legal thought managed to overcome a simplistic interpretation of reality.

Russian legal philosophers' ideas had a solid reformatory potential and a great impact on the political situation in the country, too. They substantiated the need for liberal transformations in the political sphere and set the task of state judicial policy to be the establishment of the ideas of the rule-of-law state, the supremacy of law, and formal legal equality. The "revived natural law" theory contributed to the general direction in which Russian statehood developed in the early twentieth century, its evolution from a state characterized by paternalistic attitudes towards the individual by public authority and its ambition for total regulation of the society's life, to a rule-of-law state, which was based on the supremacy of law, formal equality, and the inherent worth of the individual, his or her freedom and dignity. The liberal theory of civil rights stimulated changes in the social system of imperial Russia. It became the platform for the progressive transformation of an estate-based society into a civil society.

The legal philosophy of modern Russia is characterized by a variety of concepts of civil rights formulated by liberal juridical, sociological, integrative, communicative, and other legal theories. This offers hope that within the framework of ideological and legal variety, it will be possible to interpret the institution of individual rights and freedoms more broadly, and to comprehend conceptually the prospects for their development in the Russian Federation. The knowledge base accumulated by the Russian school of "revived natural law" is of great relevance in this respect. Its strongest point was that its representatives interpreted civil rights and the rule-of-law state on the basis of a thorough study of both the positive experience of the political and legal development of European countries, and a profound knowledge of national Russian legal culture, history and modernity.

Higher School of Economics, law faculty, Moscow

Anastasiya13@mail.ru 